\title{
Comparative comparison of music and architecture (case study: Frank Lloyd Wright falling water and Frederic Chopin Prelude No. 15)
}

\author{
Alireza Moshabaki Isfahani ${ }^{1}$ and Vahideh Mojahed ${ }^{2}$ \\ 1 Department of Architecture, Payame Noor University (PNU), P.O.BOX:19395-3697, Tehran, Iran \\ E-mail: alirezamoshabaki@yahoo.com \\ 2 Ph.D. student of Architecture, instructor of Sama Technical and vocational Training College Tehran Branch (Kan), Islamic Azad Uni- \\ versity, Tehran, Iran. \\ E-mail: mojahedvahideh@gmail.com
}

\begin{abstract}
Human being, in his life, has always expressed his emotions, feelings, and sorrows with movements and words, which can be seen in music and architecture. The performed studies in the field of architecture and music have revealed that, from a long time ago, there has always been a conceptual relationship between these two arts and both of them have represented unique concepts. The present study has a functional purpose and its method is qualitative. The data has been collected through documentary and library studies and field observations, in such a way that while introducing a preliminary knowledge of an architectural work inspired by romantic movement and a piece of music from the same time, it has been searched to discover the conceptual relationship between these two works by comparing them in order to find their similarities. The study seeks to answer the question: What is the link between the two works of music and architecture? The results suggest that there are many similarities between the two works which shows the fact that from past to today, there has always been a conceptual relationship between music and architecture, and the two arts have represented unique concepts in all periods of time. In other words, human's emotions and spirit are the sources of the arts of architecture and music, and both, in different ways, seek to convey the concept of beauty to their audience, and this common desire has led to create the link between them.

Keywords: Art. Music. Architecture. Link. Sharing.
\end{abstract}

\section{INTRODUCTION}

The study of the relationship between the space of music and architecture in the past and today has been one of the permanent discussions in the arts field. The problem of the study is the introduction of the most significant and important linkages between the two arts which are studied into three categories of expression format, expression manner and expression mode. The purpose of the research is to deeper study the shared concepts between the two arts that both of them are created under the influence of Romantic Movement.

\section{LITERATURE REVIEW}

The first people who suggested some hypotheses to prove the internal relationship between mathematics, geometry, music and architecture included Pythagoras and Aristotle. They reached rhythmic and cosmic ratios. From the mentioned contemporary researches in this field, the results of a digital design project by Chris Tenson are 
considered. He has designed parametric software containing numbers and ratios in order to generate 48 virtual forms on the basis of the preview of Johann Sebastian Bach's first book. The latest contemporary research has been performed by Martin Wattenberg. He used arc graphs to interpret the most famous art works as a graph. $\mathrm{He}$, in this study, argued that the relations existing in pre-modern periods are in contrast to the ones in the post-modern periods, and include many backgrounds. It is also compared to the conventional charts from some of the most famous modern pieces (Sohangir, 2012: 34-35).

\section{The Romanticism Movement, the Intellec- tual Foundation of Organic Architecture}

Romanticism is a literary and artistic philosophical movement which has spread to the northwest of Europe and the United states in the late eighteenth and nineteenth centuries. This movement was a reaction to the rationalism of modern reason. Geuthe (1749-1832) and Schiller (1759-1805), two famous German poets, used Romantic word versus Classic for the first time (Ghobadian, 2012: 63). The Romantics like the followers of Classic thinking believed in the mind of human. But, they focused on the feelings and emotions, and most of their philosophers were poets and they celebrated nature, emotions, and imaginations. Therefore, in classic literary and artistic works, they can be observed clarity, nonambiguity, order, symmetry, proportionality; but, in romantic works, stimulating feelings and excitement, creating ambiguity and delusions, and natural spectacular views are considered. The Classics seek to dominate nature, while the Romantics look for admir- ing the nature. Friedrich Wilhelm Schilling (1775-1854), who is considered as one the important founders of romantic philosophy, believed that nature was a part of human himself and there is no separation between man and nature (ibid, 2012: 64). Organic architecture is rooted in the Romanticism Philosophy; it can be argued that the ideas of the leaders of the Romanticism Movement and their hypotheses about the nature rules led to form the organic architecture in nineteenth century by Frank Franz and Louis Sullivan. In the early half of the 20th century, the Romanticism Philosophy as one of the main elements of organic architecture is the fixed part of Frank Lloyd Wright's architecture. Hence, in his designs, we can observe the combination of rigid and harsh elements in an artistic form which Wright himself calls it "elegance of the design". Wright believed in organic architecture and was so interested in Japanese architecture. The influence importance of external surfaces and internal spaces was one of the features of his architecture, and he always emphasized on the maintenance of harmony between man and nature. The most important aspect of his architecture was the proper use of space. From his viewpoint, man is integrated with the environment and always has a continuous connection with it. According to Wright's belief, technology is a means to achieve a higher-level architecture that, on the basis of his view, is the same as organic architecture (ibid, 2012: 67). He was one of the first people who oppose the prevailing traditional and classic thinking in architecture field and can create a new era in architecture of the world by his new ideas and thoughts. 


\section{Romantic Music}

Romantic music refers to a periodical music from the Western classic music which has begun since the late eighteenth century. The music is related to the Romanticism Movement. For romantic composers, it was not just about portraying nature, but it was also considered a deep link between nature and inner lives of musicians which were the sources and inspirations of their art. Of the main features of romanticism is the transformation of some classic features including strict rules, order and balance, integrity and control. The clarity and non-ambiguity that were of the main aspects of the Classics were replaced by a type of deliberate ambiguity and symbolic expression for the Romantics. Focus on the emotional aspects of the artist, not following the constant and strict rules and following mental desires, the respect for human emotions and spiritual issues, using art as a means of stimulating emotions and freedom, are all of the features of this style.

\section{The Concept of the Expression Format in Architecture and Music}

Human being is a social creature and one of the most important needs of human is to communicate with his fellows and to create a relationship between realization and understanding, and language is the most important means of this relationship. Language is a set of contractual symbols which is used along a dimension (time) to convey messages. Also, in every original art, artists for expressing their inner selves require a system of contractual symbols to communicate with their audiences. The system, which in fact is the language of any artistic branch, is not a unique language, and in various arts appears in different forms.

In painting, sculpture and show, the expression format is as an object, and human is on that environment. Expression format in painting is a two-dimensional screen, in sculpture, a three-dimensional figure, and in show, the volume of the scene. It should be noted that space in itself is shapeless and is realized by its components. In the arts of architecture, music and cinema, the expression format is from space. The space surrounds human being (Keramati, 2016). To create each unit of space, there is a need to three key words of wall, ceiling, and floor. In other words, architecture art is to express the emotions of artist in a sample space, consisting of a rectangle, four walls, a ceiling and a floor (ibid). Music is an art with a completely symbolic language in the service of artist whose existential nature is abstract and subjective. The space genre which is the format of musical expression is audio space, and does not provide visual or eye images, but creates audio images to communicate with its audience. The required key words for these audio images are pitch, rate and section. Finally, in cine$\mathrm{ma}$, the space genre is audio-visual.

\section{The Concept of Expression Manner in Ar- chitecture and Music}

Expression manner in architecture is the same as style that different artists have different style for themselves. When an architect artist chooses some terms for collocating with wall, ceiling, and floor, he actually sets out his expression manner, and this is where the substantive form of a work begins to take shape. In music, there are also different manners for expressing a work, 
and musician creates his work through its help and reaches the musical form of the work.

\section{The Concept of Expression Mode in Archi- tecture and Music}

The chosen vocabulary by an architect artist, which are actually the natural or artificial material that he uses in the geometry of the built space to express a feeling (ibid), express the concept of mode in architecture. In music art, the selected vocabulary, which have audio genre, are also chosen by musician.

\section{The Introduction of Architecture Work}

Fallingwater or Kaufmann's residence is one of the outstanding works of the famous architect, interior designer, and writer, Frank Lloyd Wright (1867-1959), which has been constructed in $69 \mathrm{~km}$ of the southeast of Pittsburg city, Pennsylvania state, and on the northern coast of Bear Run River in 1935. Fallingwater was quickly brought up all over the world because of its unique design and position. It was called the most beautiful architectural work of Frank Lloyd Wright by Time Magazine; and several months later, in the Smithsonian Journal, it was introduced as one of the 28 places that should be seen before death. Fallingwater was listed on the US National Historic Heritage List in 1966. Moreover, in the 2007 survey, AlA Institute ranked the work as the 29th most popular architectural work in the United States of America.
Picture 1: using glass instead of wall

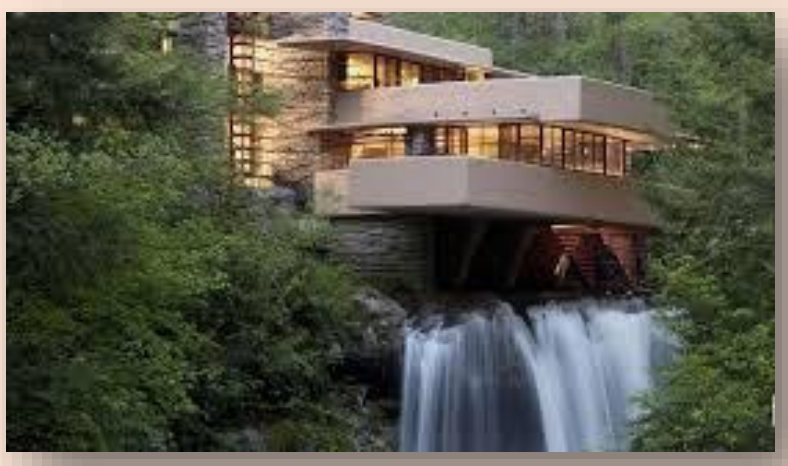

Source: www.freshome.com

The Analysis of the Work in the area of Expression Format

- The constituted space

- The integration of building size with the natural environment

- Placing on the waterfall

- All around with glass screwed horizontally instead of wall

Picture 2: using the all-around glass

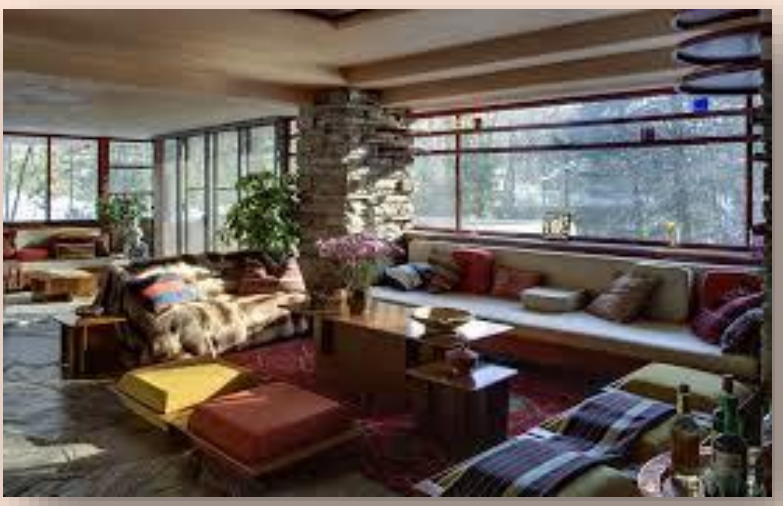

Source: www.fallingwater.org

- A few walls and transparency in space

- Integration with considering the generalized and total details to secondary and partial details 
Picture 3: cliff-like beams of terraces

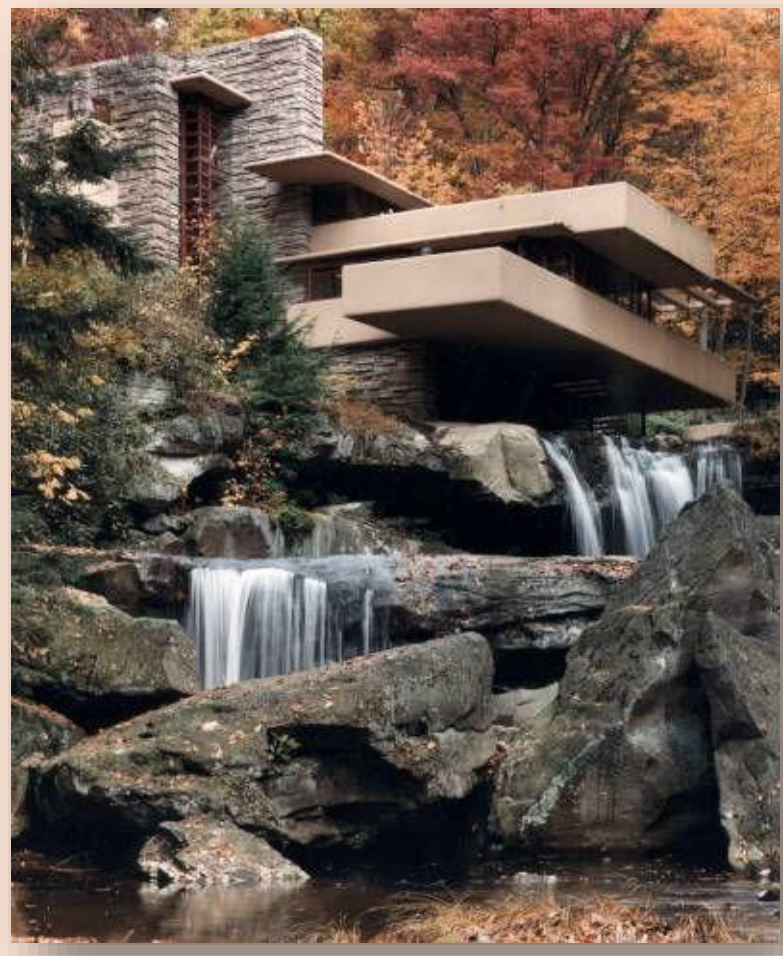

Source: www.pinterest.com

- Consoling the roof and its horizontal position parallel to the ground

- Beams of terraces being almost like cliffs

- Eroded rocks for building the roof of the house

Picture 4: main floor plan

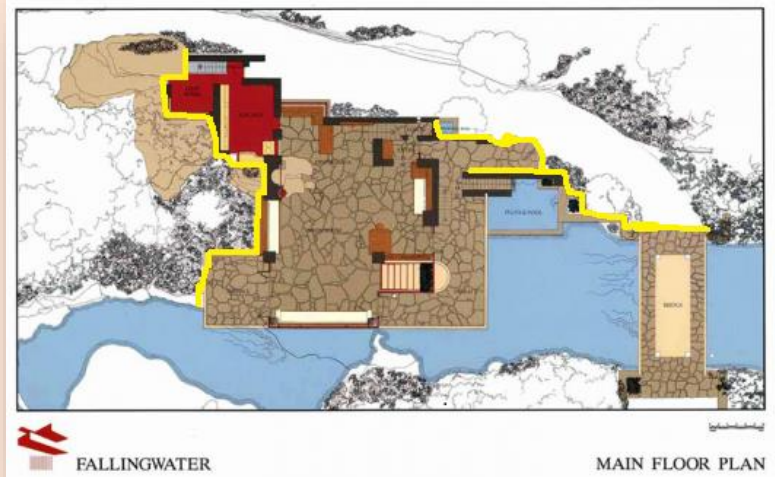

Source: www.archdaily.com
- Using the natural stone for the floor of the main floor

- Moving the floors plan parallel to the surrounding natural environment

- Consistency of applied materials for floors, entrance and terraces

- Polishing the stones of the floor

Picture 5: shape of floor materials

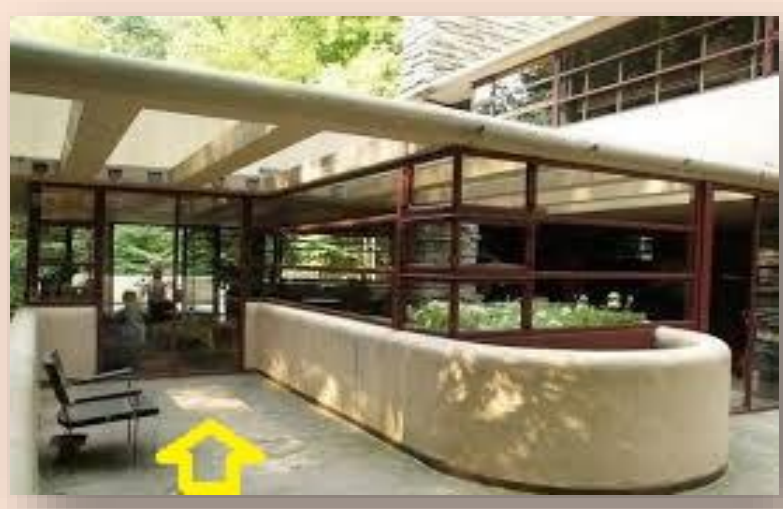

Source: www.pinterest.com

Picture 6: shape of floor materials

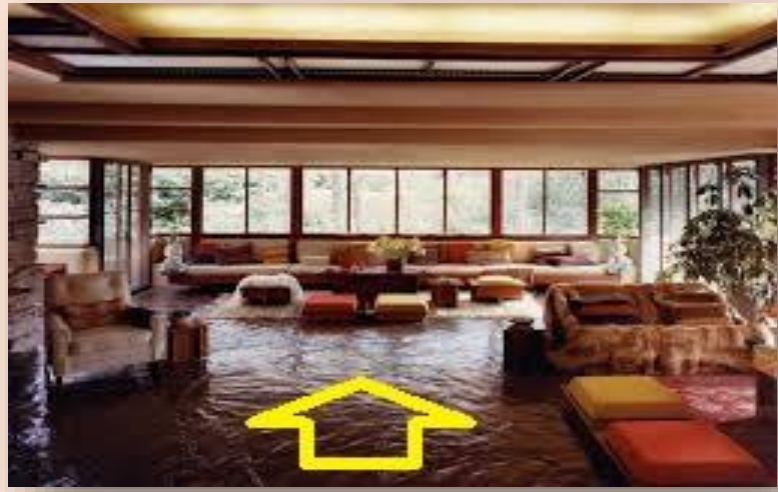

Source: www.wright-house.com

The Analysis of the Work in the area of Expression Manner

Fallingwater has been built in the style of organic architecture which is rooted in romanticism philosophy. The features of this 
building are:

- Parapet with eaves and network-like windows to enhance horizontal and vertical uniformities

- Cantilever concrete plates

- Its horizontal layers, free from apparent retaining, come up the waterfalls and brook's basins

- The influence importance of external surfaces and internal spaces

- Along with the stairs from the living room to the creek down the house

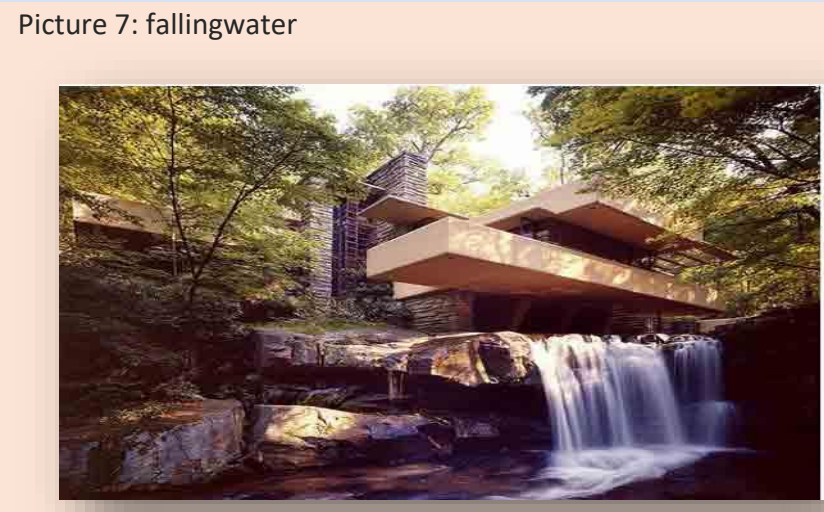

Source: www.designrulz.com

- Placing the house on the rock, at least interfering with the natural architecture

- Proper use of spaces

Picture 8: placing the house on the rock

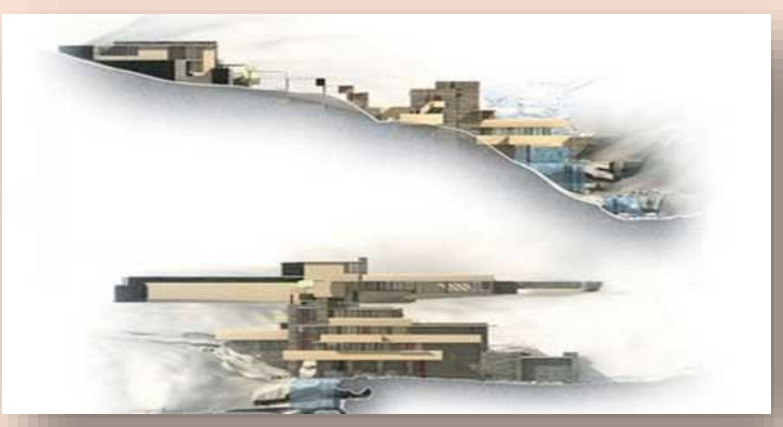

Source: www.archdaily.com
- Natural manifestations of composition (undressed stones) and manifestations

- Constant display of materials from inside to outside of the building

- Horizontal expansion in all central directions

Picture 7: display of materials

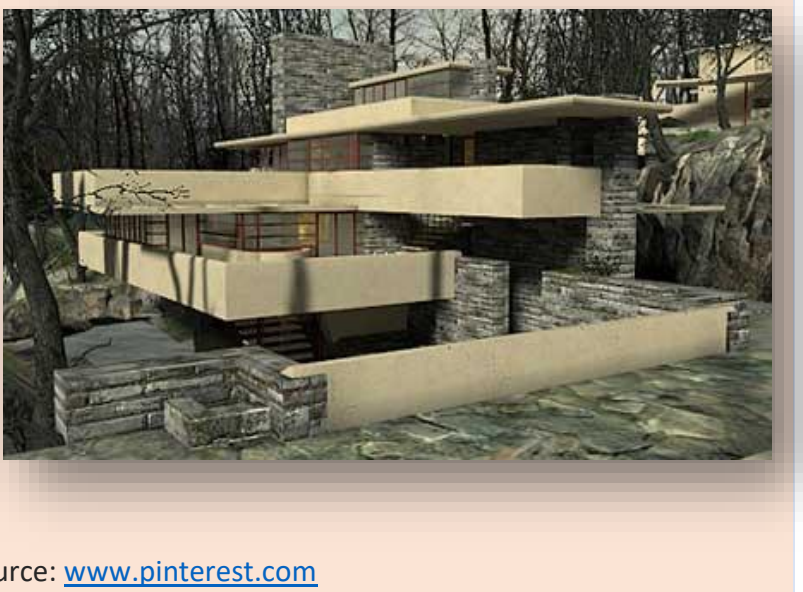

Picture 8: display of materials

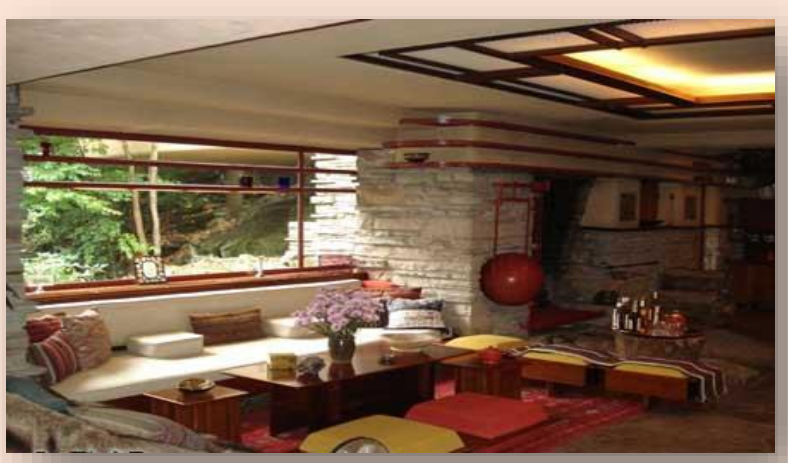

Source: www.fallingwater.org 
Picture 9: second floor plan

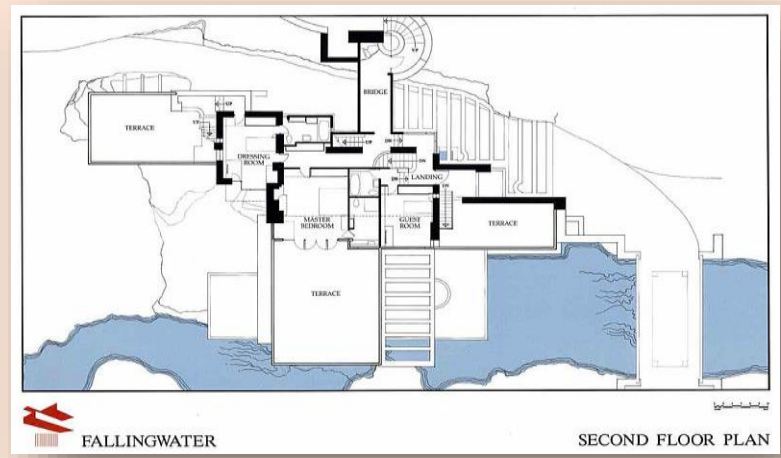

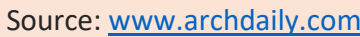

Picture 10: third floor plan

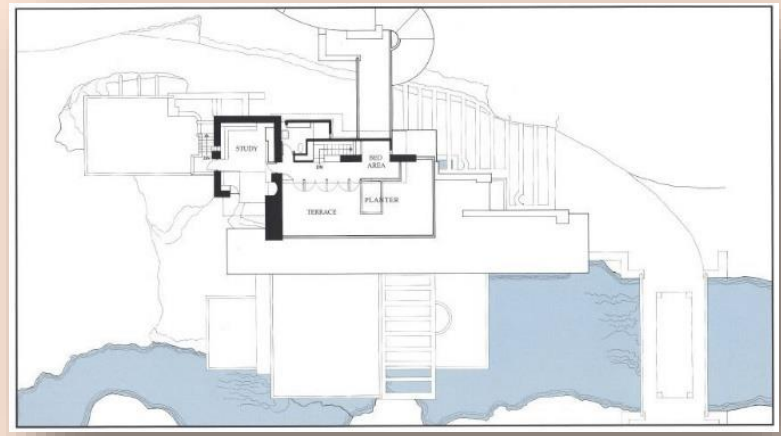

Source: $\underline{w w w . a r c h d a i l y . c o m}$

Picture 11: first plan of guest floor

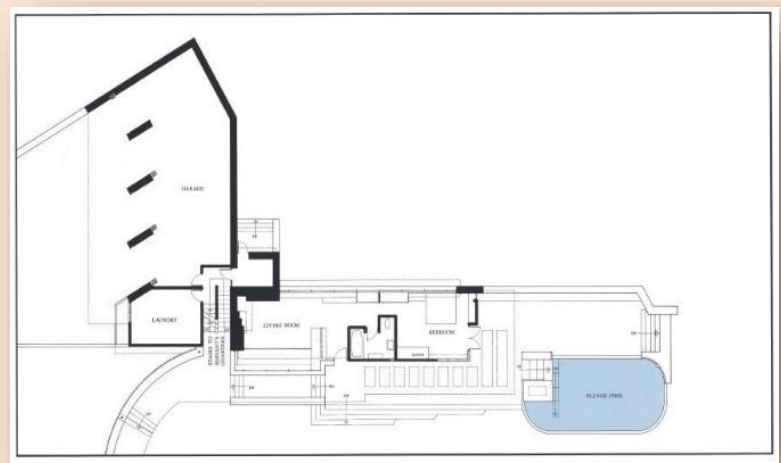

Source: $w w w$. archdaily.com
Picture 12: second plan of guest floor

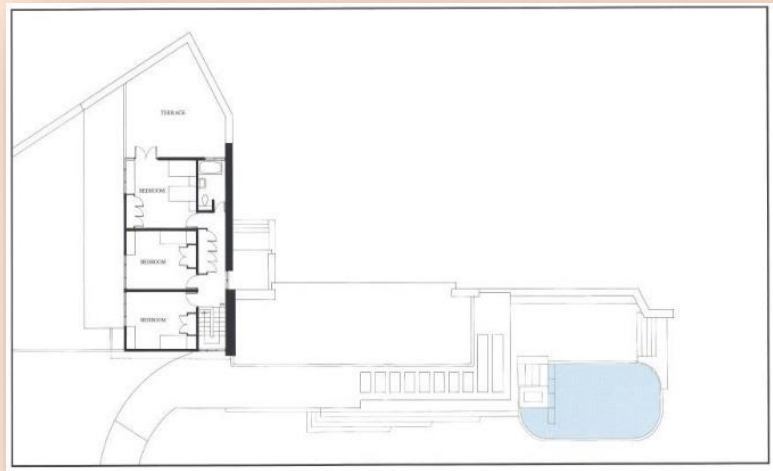

Source: $w$ ww.archdaily.com

Picture 13: main vertical and horizontal lines

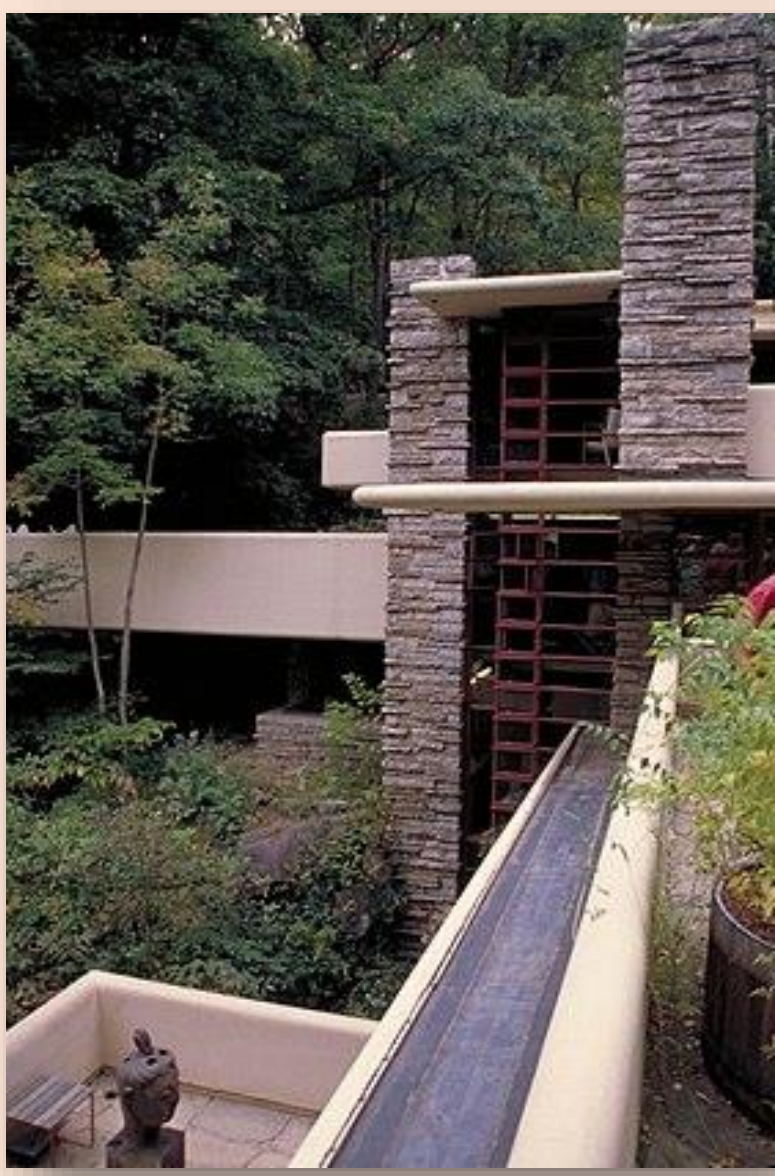

Source: www.wright-house 
The Analysis of Work in the area of Expression Mode

- Main vertical and horizontal lines of the distinct sections

- Conformity and harmony

- Bright red ground soil for concrete section

- A special red color (called Cherokee) for steel sections

- Natural factors like rocks, trees, plants and flowers are grown in the nature

- The display of materials the same as they are, whether they are rocks, wood or bricks

- Beautiful moving of waterfall under the house

\section{Introduction of Music Work}

Fredrick Francois Chopin was one of the most influential Polish musicians and the outstanding pianist in the Romantic era (1810-1849). His most important innovations were in the forms like Piano Sonata, Waltz, Nocturne, Etude, Prelude, Polonez.

Prelude 15 from opus 28 of Chopin is his longest and most beautiful prelude works. Chopin sang this prelude during his stay in his friend's house, George Sand, in one of the Spain's islands named Mallorca Valldemossa.

Chopin with Sand went to the island to escape the cold winters of Paris and improve his lungs. George Sand when heard this piece for the first time called it the drops of rain. The reason of naming this piece as the drops of rain is due to the repetition of $A B$ note (Lampl) all round this prelude that is reminiscent of rain drops. Chopin was not so satisfied with the names that others put on his pieces, but the name of rain drops remained on this piece from that time.

Picture 9: Fredrick Chopin

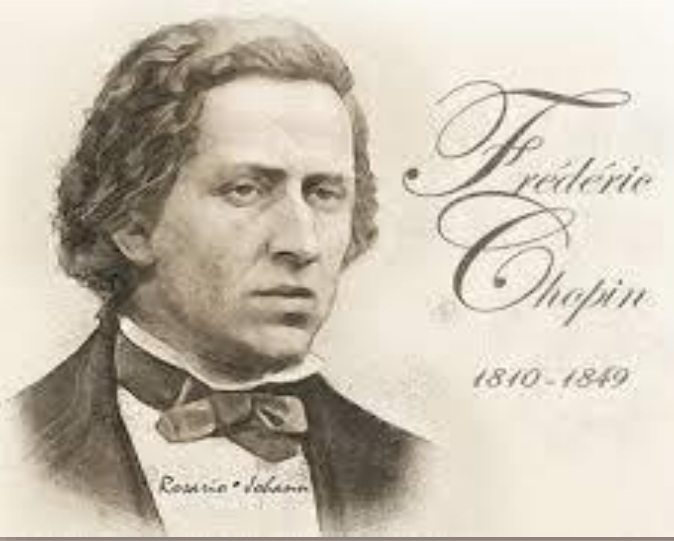

Source: www.classicfm.com

The Analysis of the Work in the area of Expression Format

- Expression format: audio space

- Similarities of A\&B

- Similar Tempo

- Similar Bar measurer

- Scale: Rambel Major

- Bar: 4 beats

- Piece form: independent Prelude

- Musical and structural form: three-part returnable

Table 1: segmentation of the piece (source: the author)
\begin{tabular}{|l|l|l|}
\hline Bars & Scale & Part \\
\hline 27 & Rambel major & A \\
\hline 20 & c-sharp minor & B \\
\hline 8 & Rambel major & A \\
\hline 6 & Rambel major & coda \\
\hline
\end{tabular}

The Analysis of the Work in the area of Expression Manner

- Start with a smooth and calm theme in 
the part A with the right hand (Sol key)

- Start the theme in the part A in contradiction with the part $B$ and restart the theme A

- Final part: theme repeating in shortening and extending the tonic

- the rhythm with few tracks and clear expression

- At the same time as starting the start theme in the right hand, the repeatable note (Lampl) in the left hand is appeared being the reminiscent of rain drops.

- Using the main theme in the method of thematic variations

- The presence of the repeatable Lampl note to the end of the part A

- Sol key (red flash)

- Fa key (blue flash)

- Lampl (purple flash)

Picture 1: piece analysis

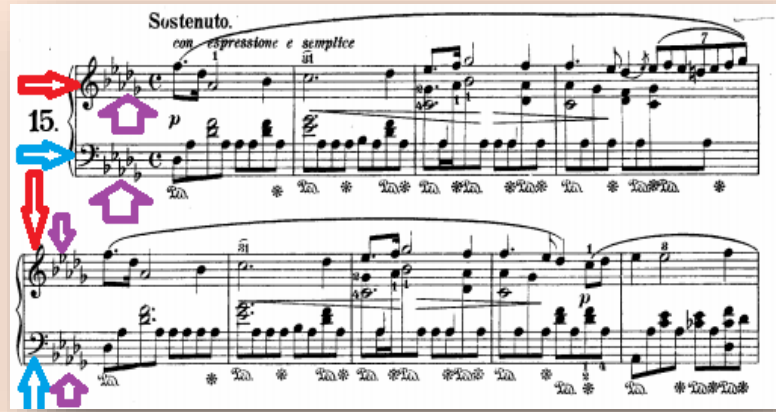

Source: the author

- In the part B, the repeatable Lampl note is replaced by G-sharp note (red flash).

- This has a significant role in the continuity and unity of the piece.

- Exquisite movements in the harmonic cycle

- Increasing the dramatic aspect of the piece due to the use of the harmonic joints with extremely abnormal solu- tions

Picture 2: piece analysis

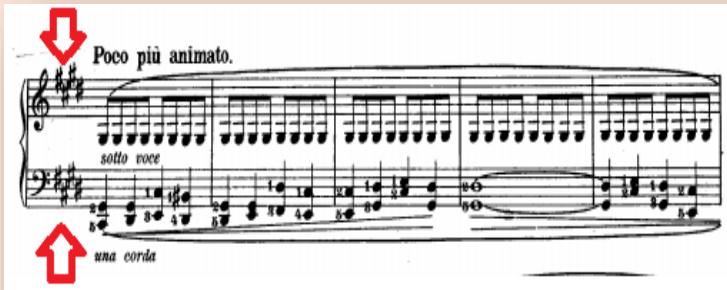

Source: the author

- Homophonic texture

- Tonal harmony

- Creating dramatic space due to the contrast of the parts $A$ and $B$

- Distance as well as unity

- Using temporary exits and numerous modulations

- Cuts

Picture 3: the piece form (source: the author)

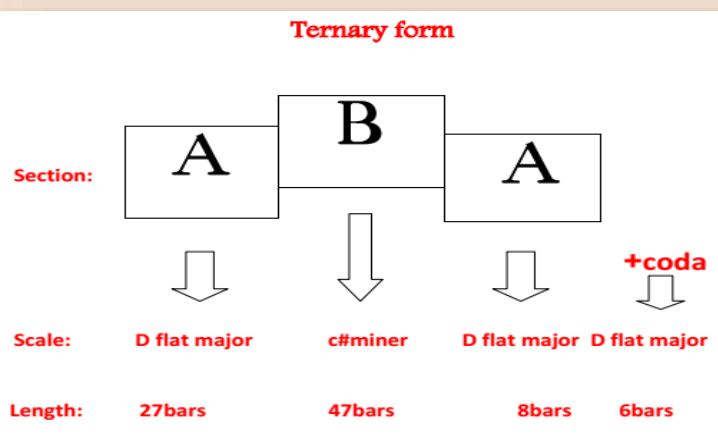


Table 2: the comparison of the two artistic works (source: the author)

\begin{tabular}{|c|c|c|}
\hline & Fallingwater & $\begin{array}{l}\text { Prelude, number } \\
15\end{array}$ \\
\hline $\begin{array}{l}\text { Expression } \\
\text { Format }\end{array}$ & Space & Audio Space \\
\hline $\begin{array}{l}\text { Expression } \\
\text { Manner }\end{array}$ & $\begin{array}{l}\text { Organic (inspired by } \\
\text { Romanism Philoso- } \\
\text { phy) } \\
\text { Few walls and } \\
\text { clarity in space } \\
\text { Repetition and } \\
\text { cycling of glasses all } \\
\text { around the building } \\
\text { Trimmed volumes } \\
\text { from concrete as } \\
\text { smooth and pol- } \\
\text { ished and boulders } \\
\text { for constructing the } \\
\text { roof of the house } \\
\text { The conformity of } \\
\text { the applied materi- } \\
\text { als for floors, en- } \\
\text { trance, and terraces } \\
\text { Natural and artifi- } \\
\text { cial manifestations } \\
\text { together }\end{array}$ & $\begin{array}{l}\text { Romantic } \\
\text { Rhythm with few } \\
\text { tracks and very } \\
\text { clear expression } \\
\text { The presence of } \\
\text { the repeatable } \\
\text { Lampl note to the } \\
\text { end of the part A } \\
\text { The presence of } \\
\text { exquisite move- } \\
\text { ments in harmonic } \\
\text { cycles } \\
\text { Continuity and } \\
\text { unity and con- } \\
\text { formity of the } \\
\text { piece } \\
\text { Using the harmon- } \\
\text { ic joints with } \\
\text { abnormal solu- } \\
\text { tions }\end{array}$ \\
\hline $\begin{array}{l}\text { Expression } \\
\text { Mode }\end{array}$ & $\begin{array}{l}\text { Conformity and } \\
\text { harmony } \\
\text { Main vertical and } \\
\text { horizontal lines of } \\
\text { the distinct sections } \\
\text { The presence of } \\
\text { natural factors like } \\
\text { rocks, trees, plants } \\
\text { and flowers, and } \\
\text { the display of mate- } \\
\text { rial in the same way } \\
\text { as they are } \\
\text { Using the bright red } \\
\text { ground soil for the } \\
\text { concrete section } \\
\text { and a special red } \\
\text { color (named Cher- } \\
\text { okee) for steel } \\
\text { sections } \\
\text { The beautiful mov- } \\
\text { ing of the waterfall } \\
\text { under the house }\end{array}$ & $\begin{array}{l}\text { Tonal harmony } \\
\text { Creating the dra- } \\
\text { matic space due } \\
\text { to the contrast of } \\
\text { the parts A and B } \\
\text { Homophonic } \\
\text { Texture } \\
\text { Using the tempo- } \\
\text { rary exits and } \\
\text { numerous modu- } \\
\text { lations } \\
\text { Smooth and calm } \\
\text { theme in the part } \\
\text { A }\end{array}$ \\
\hline $\begin{array}{l}\text { The Selected } \\
\text { Vocabulary }\end{array}$ & $\begin{array}{l}\text { Consolidating with } \\
\text { natural environ- } \\
\text { ment - blending of } \\
\text { spaces-plain surfac- } \\
\text { es-vertical and } \\
\text { horizontal lines } \\
\text { Using just two } \\
\text { special colors }\end{array}$ & $\begin{array}{l}\text { Homophonic } \\
\text { Texture } \\
\text { Tonal Harmony } \\
\text { Modulation }\end{array}$ \\
\hline
\end{tabular}

\section{CONCLUSION}

From long time ago, there has always been a conceptual relationship between the two arts of architecture and music, and both have introduced unique concepts. In the comparison of fallingwater with Chopin's rain drops, it seems that the two works share many similarities and represent shared concepts to the audience.

In fallingwater, the maintenance of the calmness of the forest, river and the rock was so significant, and all of these as well as the structure of the house and its consistency with the surrounding nature invite you to calmness and listening to soft sounds: the music of water and waterfall. In contrast, the most important features of Chopin's piece are also unity and consistency all over the piece; the unity with attracts you to listen to the end of the piece.

The type of the material and the house's texture from external view are not from the nature's type, but it has been hidden in the nature in such a way that you are attracted. This difference is also felt in Chopin's rain piece. The change of modulation, the shift of contrast and dynamic are enough to make you excited.

It seems that increasing the dramatic aspect of the piece due to the use of the harmonic joints with numerous abnormal solutions that have been happened in this piece and have made you to listen carefully has the same courage that Wright used in preprepared consules in fallingwater.

\section{REFERENCES}

Sarabi, p. (2011). Ontology of "expression" and "expressing" in music with the ap- 
proach of Iranian music. Asalemi, Tehran, Kimiaye Honar Journal. 1(1).

Sohangir, S. \& Norouz Borazjani, V. (2012). The comparative study of the conceptual link between architecture and music spaces in pre-modern and post-modern periods in West World. Baq Manzar Journal. 3 (33). Chopin, F. (1949). Chopin's Waltz for piano, ed. Willard A. Palmer, new york, An Alfred Masterwork Edition Ghobadian, V. (2011), West's Contemporary Architecture, Tehran, cultural researches office.

Keramati, Gh. (2016), PhD Course notes of common language of architecture and other arts.

Manafzadeh, H. (2012). Form, space, and architecture, strategic view to design and creation of form in architecture. Tehran, the first national conference of thoughts and new technologies in architecture.

Yaghouti, S. \& Kazemi, M. (2014). The comparative study of the identity of Iranian architecture and Iranian music (the link of music and color). Mashhad, the ninth symposium of the development of science and technology.

Robinson, J. (1997). Music and meaning. United States of America: Cornell University Press.

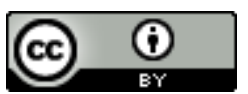

License information: This is an openaccess article distributed under the terms of the Creative Commons Attribution License, which permits unrestricted use, distribution, and reproduction in any medium, provided the original work is properly cited.

Article received on February 13, 2019.

Evaluated July 26,2019.

Accepted on August 05, 2019.

Published on August 07, 2019.
How cite this article (ABNT):

ISFAHANI, Alireza Moshabaki; MOJAHED, Vahideh. Comparative comparison of music and architecture (case study: Frank Lloyd Wright falling water and Frederic Chopin Prelude No. 15). Estação Científica (UNIFAP), Macapá, v. 8, n. 3, p. 37-47, Sept./ Dec. 2018. 